\title{
Badacz i jego perspektywy interpretacyjne w studiach nad dziejami nauki
}

\section{The Researcher and Their Interpretative Perspectives in the Studies on the History of Science}

A historian (also of medicine) should accept the values and canons of the studied culture, including medical ones, as their own. As Florian Znaniecki pointed out in his works, they should be the researcher's highest authority. This means that the researcher should deviate from evaluating the ideas and practices of the studied culture from their own perspective. The category of minimal cultural imputation developed by Wojciech Wrzosek shows that it is not an easy process. However, the application of the subjective-rational perspective to the interpretation has already become an obvious approach. An open and much less obvious problem is the role of the historian of science when they venture to make comparisons between past and present scientific cultures. By doing so, do they still remain a historian, or - by undertaking such comparisons and evaluations - do they abandon the role, assuming the position of, for example, methodologist? The author of the article outlines the possibilities of separating these roles, presenting the attitude of a 'methodologist' who searches in the past for the roots and theoretical justifications for contemporary paradigms of their discipline, using the latter to evaluate the past. However, the possibility of a non-evaluative dialogue between the cognizing culture and the cognized culture is also shown, where the former also includes the specialist knowledge of a contemporary researcher interested in the past of their discipline. The historiography of a given science appears here as a record of the self-knowledge of a given generation of researchers - as their self-reflection. As Jan Pomorski calls it, a researcher assuming such a role appears as homo metahistoricus in their field of study.

Keywords: historiography of science, history of science, cognizing cultures - cognized cultures, researchers' social roles with respect to the past, homo metahistoricus

Słowa kluczowe: historiografia nauki, historia nauki, kultury poznające - kultury poznawane, społeczne role uczonych wobec przeszłości, homo metahistoricus

Historyk nauki, także medycyny, winien przyjąć wartości i kanony badanej kultury, także medycznej, jako własne. To one, jak wskazywał w swoich pracach Florian Znaniecki, a po nim wielu historyków i antropologów kultury, są dla badacza najwyższym autorytetem. 
Oznacza to, że badacz powinien odejść od wartościowania idei i praktyk kultury badanej z perspektywy własnej. Znaniecki, socjolog kultury, tak pisał o tym przed niemal stu laty:

występując w roli badacza, nie ma on prawa zastanawiać się nad tem, czy zjawiska, dane mu jako „wiedza” pewnej epoki i społeczeństwa, są istotnie wiedzą z punktu widzenia tego ideału poznania, który on sam uznaje jako rozstrzygający, czy i w jakiej mierze są one nie tylko zjawiskami, ale i prawdami w jego oczach, logicznie uzasadnionemi wobec tych sprawdzianów, jakie on sam obecnie przyjmuje. Takie usunięcie wartościowania badanych zjawisk z badań nad wiedzą może być trudne wobec tego, że sami, tworząc lub przyjmując teorje naukowe, przywykliśmy poddawać krytyce cudze i własne twierdzenia. [...] Jasnem jest, że musi w wyborze zjawisk do badania stosować się do sprawdzianów prawdziwości, uznawanych przez ludzi, którzy dane zjawiska poznawcze przyjmowali lub przyjmują za prawdziwe, musi uważać za „wiedzę" - to wszystko, co w badanych przezeń okresach i zbiorowościach było lub jest za wiedzę uznawane. Tym sposobem jedynie uniknie on niebezpieczeństwa podsuwania pod zjawiska z góry powziętej koncepcji o właściwej istocie tych zjawisk, naginania danych historyczno-kulturalnego doświadczenia do swego subjektywnego przekonania, jakiemi te dane być powinny. Takie postępowanie teoretyka wiedzy zgodnem będzie z ogólną wytyczną wszystkich nauk humanistycznych, których zasadniczą cechą, w odróżnieniu np. od nauk przyrodniczych, jest rozpatrywanie badanych zjawisk w tej postaci, w jakiej były one lub są faktycznie doświadczane przez ludzi, mających z niemi praktycznie do czynienia, czyli przez jednostki i grupy, żyjące w odnośnych historycznych okresach i miejscowościach?1.

Niewielu historyków nauki po stu latach podważyłoby dziś ten pogląd, choć myśl Znanieckiego nie jest wśród nich szczególnie popularna.

Opracowana przez historyka historiografii Wojciecha Wrzoska kategoria minimalnej imputacji kulturowej wskazuje jednak, że zarysowany przez Znanieckiego proces nie należy do łatwych. Poznański metodolog zaliczył do niej:

1. klasyczny rachunek logiczny, 2. temporalność i specjalność, 3. elementarne zdania egzystencjalne oraz 4. stereotypy społecznego myślenia. Jednak badacz realizujący strategię poznawczą opartą na wierze w obiektywność metafor kulturowych, w tym historycznych jest w swoim mniemaniu tropicielem obiektywności realności i konkretności prawdy. Poznać oznacza dla niego: ustalić prawdę, wyjaśnić zjawisko².

Oznacza to, że badacz systemów wiedzy odmiennej, zatem także minionej kultury, nie do końca jest w stanie kontrolować postulowany przez Znanieckiego proces, właśnie ze względu na ową minimalną i nie uświadamianą sobie imputację kulturową. Jednakże zastosowanie tu interpretacji wartościującej z perspektywy subiektywno-racjonalnej, używanej m.in. przez Jerzego Kmitę, a więc biorącej pod uwagę optykę podmiotu działające-

1 F. Znaniecki, Przedmiot i zadania nauki o wiedzy, „Nauka Polska. Jej potrzeby, organizacja i rozwój” t. 5, 1923, s. $11-12$.

2 Szerzej o idei minimalnej imputacji kulturowej zob. W. Wrzosek, O myśleniu historycznym, Bydgoszcz 2009, s. $13-27$. 
go, a nie badacza, należy już wśród badaczy kultury do oczywistych ujęć, także w historii nauki.

Nieco inaczej rzecz się ma z inną konstatacją Floriana Znanieckiego, który pisał o postawach socjologa:

Oczywiście, gdy uroszczenia cudzych systemów poznawczych krzyżują się z uroszczeniami własnego jego systemu, może wysunąć własne, jak to czynimy tutaj, w sprawie socjologii wiedzy; na ten czas jednak przestaje być socjologiem, badaczem osób i grup, zajmujących się wiedzą, a występuje jako normatywny filozof wiedzy ${ }^{3}$.

Jeżeli bowiem zamienimy w tekście tej wypowiedzi socjologa wiedzy na historyka nauki, to znajdziemy się w samym środku kontrowersji dotykających to środowisko. Stosowanie współczesnych standardów racjonalności naukowej jako obiektywizującej interpretacji dawnych systemów wiedzy, np. medycznej, i pozwalających na przeprowadzenie porównań między nimi na takiej właśnie płaszczyźnie, nie należy do wyjątków.

Także interpretacja Jerzego Kmity, wiążąca koncepcje współczynnika humanistycznego przywołanego socjologa i paradygmatu Thomasa Kuhna, mało w środowisku historyków nauki zresztą znana, nie może zażegnać konfliktu. Ten pierwszy pisał bowiem:

Rezultaty praktyki badawczej danego okresu historycznego, w szczególności teorie naukowe, wyposażone są w określony społeczny współczynnik humanistyczny. [...] Składa się nań aktualna społeczna świadomość metodologiczna oraz akceptowane na jej gruncie dotychczasowe rezultaty badawcze. [...] Poza tego rodzaju zlokalizowanym historycznie współczynnikiem humanistycznym teoria naukowa nie istnieje jako społeczny twór kultury. Oczywiście społeczna świadomość metodologiczna ulega zmianom rozwojowym, odpowiednio metodologiczno-teoretyczne współczynniki humanistyczne następujących po sobie teorii różnią się od siebie niejednokrotnie w sposób radykalny. Jeżeli przeto zakłada się możliwość uniwersalnego, ponadczasowego porównywania logiczno-_empirycznego" poszczególnych teorii, to jest to przejaw ahistoryzmu w traktowaniu owej świadomości metodologicznej. [...] Tak więc ci wszyscy, którzy nie zdają sobie sprawy z faktu, że teoria naukowa jest określonym obiektem kulturowym z uwagi na odpowiedni współczynnik humanistyczny, a tym bardziej z faktu, że ów współczynnik ukonstytuowany jest przez zmienny historycznie obszar świadomości społecznej, po prostu abstrahują akceptowane przez siebie (niekiedy w trybie czysto indywidualnym) normy i dyrektywy metodologiczne. W gruncie rzeczy zatem głównym osiągnięciem T.S. Kuhna jest wprowadzenie własnego terminu „paradygmat” dla metodologiczno-teoretycznego współczynnika humanistycznego kolejnych stadiów rozwoju wiedzy naukowej oraz podkreślenia jego roli jako społeczno-subiektywnej bazy wykrystalizowania się standardu „naukowości”4.

Warto tu pokreślić współgrające z interpretacją Znanieckiego sformułowanie, że „jeżeli przeto zakłada się możliwość uniwersalnego, ponadczasowego porównywania logicz-

3 F. Znaniecki, Społeczne role uczonych a historyczne cechy wiedzy (1937), [w:] idem, Społeczne role uczonych, tłum. i red. J. Szacki, Warszawa 1984, s. 524.

4 J. Kmita, Szkice z teorii poznania naukowego, Warszawa 1976, s. 113-114 i 121. 
no-«empirycznego» poszczególnych teorii, to jest to przejaw ahistoryzmu w traktowaniu owej świadomości metodologicznej".

Otwartym i znacznie mniej oczywistym problemem jest zatem rola historyka nauki, gdy waży się on na dokonanie wartościowania minionej i współczesnej kultury naukowej. Czy wykazuje się podejściem ahistorycznym? Czy czyniąc to, pozostaje w dalszym ciągu historykiem, czy też, podejmując się takich porównań i ocen, wychodzi z roli historyka, przyjmując rolę np. metodologa? Czy da się tu zaadoptować poglądy Znanieckiego, stojącego na stanowisku, że w takim przypadku badacz wychodzi z roli socjologa kultury, a zajmuje pozycję normatywnego filozofa?

Problem dotyczy historii nauki bardziej niż innych jej dziedzin. Wynika to z faktu, że badaczem przeszłości jest tu częściej przedstawiciel badanej nauki, rzadziej uniwersytecki historyk. Oznacza to z reguły z jednej strony gruntowną znajomość swojej dyscypliny wraz z jej zapleczem teoretycznym, z drugiej natomiast interpretację jej dziejów i wiążące się nią oceny z perspektywy współczesnych mu paradygmatów i metodologii badań. Czy zatem lekarz historyk medycyny dokonujący ze współczesnej perspektywy ocen dawnych terapii pozostaje jeszcze historykiem, czy wchodzi w inną rolę? Czy zabieg taki jest metodologicznie uzasadniony, jeżeli porzucił on subiektywno-racjonalną interpretację działań dawnych terapeutów i sterujących nimi idei?

Rodzi to kolejne problemy, które muszą zmierzać w kierunku określenia warunków dla badań porównawczych pomiędzy kulturami medycznymi minioną i współczesną, a także teoretycznej postawy badacza. Jaki jest status badacza i badań komparatystycznych pomiędzy nauką dawną i współczesną, historyczny, interdyscyplinarny czy transdyscyplinarny? Czy przysługuje status historyka nauki uczonemu, poszukującemu w przeszłości uzasadnień dla obowiązującego obecnie w jego dyscyplinie paradygmatu, czy też raczej jest metodologiem danej dyscypliny naukowej, gdzie historia nauki jest tylko teoretycznym narzędziem?

Graniczność historii nauki również wywołuje refleksje. Zwracał na nie uwagę Hans-Jörg Rheinberger, pisząc:

historia nauki stoi między frontami, z wszystkimi niekorzyściami, ale też korzyściami takiej granicznej egzystencji. Szansa polega przede wszystkim na tym, że może określać swoją pozycję względnie swobodnie w transdyscyplinarnej perspektywie, i mogłaby znaleźć ostoję w odpowiednich instytucjach. Do niekorzyści braku instytucjonalizacji należy to, że regularny dialog fachowych kompetencji i historycznych, filologicznych, filozoficznych, a także socjologicznych refleksji metodologicznych, dotyczy tylko niewielu spraw ${ }^{5}$.

To nie jest tylko garść teoretycznych pytań. Szczególnie w obrębie historii medycyny tworzą one realne problemy, gdy sięgający swoją dysertacją doktorską w przeszłość lekarz otrzymuje na uczelni medycznej stopień z zakres medycyny, nie historii. Jaki jest jego status, szczególnie gdy na co dzień praktykuje w szpitalu, gdzie owo „dr med." przed nazwiskiem jest dla nie zorientowanego pacjenta wyznacznikiem jego wysokich kompetencji medycznych? 
Do „metodologów” można zaliczyć dziejopisów medycyny o przygotowaniu medycznym, ale również innych nauk, którzy interpretują przeszłość z perspektywy współczesnych im założeń teoretycznym i praktyk terapeutycznych, poszukując ich uzasadnień w przeszłości. Ma to ukazać historyczne korzenie współczesnych standardów racjonalności naukowej w naukach medycznych (i innych), przedstawiając te ostatnie jako konstrukt obiektywny i, dzięki długiemu trwaniu, ponadczasowy. I tylko takich poszukują, inne praktyki lecznicze i związane z nimi formy świadomości traktując najwyżej jako „ślepe uliczki” w rozwoju nauk medycznych, prezentowane jedynie w celach dydaktycznych. W takim rozumieniu historia medycyny staje się częścią np. nauk medycznych, gdzie o jej charakterze decydują obowiązujące tam paradygmaty. W tym znaczeniu mamy zatem do czynienia z historią wewnętrzną, gdzie przeszłość nadaje spójność teoretyczną współczesności. Historia konserwuje też współczesność. Stąd przewodnie wątki narracji to narracje sukcesów, nie ma tu miejsca na ukazanie klęsk. Dobrze ilustruje ten proces Reihnberger, mówiąc w wywiadzie z Janem Surmanem, że

to, co się nie powiodło, zostaje szybko zapomniane; więcej się już o tym nie mówi. Równolegle z realizacją Human Genome Project prorokowano, że dzięki inżynierii genetycznej w progu stoi już terapia genowa. W latach 90. XX wieku próby te ogólnie mówiąc nie udały się. Wtedy nikt już więcej o tym nie mówiłt

Owa postawa, bardziej metodologa niż historyka, jest odległa od postulatów Znanieckiego i wizji teoretycznych Kmity. Bywa uzupełniona wyposażeniem kulturowym takiego badacza. Dwa cytaty pochodzące z różnych epok pozwolą ją dobrze scharakteryzować. Ludwik Fleck, przecież lekarz, mikrobiolog, twórca ciągle będącej źródłem inspiracji koncepcji kolektywu i stylu myślowego, pisał w swoich uwagach O niektórych swoistych cechach myślenia lekarskiego:

Przyrodnik z reguły nie zauważa zjawisk socjologicznych, niektórym w ogóle nie można ich pokazać. Od rozmyślnego abstrahowania od pewnej postaci, aż do niezdolności spostrzegania ich jest więc przejście ciągłe. Żeby zobaczyć jakąkolwiek określoną postać z jakiejś dziedziny, trzeba być w stanie swoistego pogotowia myślowego, składającego się także z mniej lub więcej przymusowego abstrahowania od możliwości innych postaci

Za swoiste uzupełnienie można uznać analizę metafor Wrzoska:

Metafory dominujące w danej kulturze, w tym i te, które fundują daną dziedzinę nauki, w pewien sposób „modelują” dziedzinę badaną. Dzięki głębokiemu zakorzenieniu w kulturze „neutralizują się” i wreszcie - obiektywizują się w myśleniu interpretatora. Oznacza to, że w sposób niekontrolowany sterują interpretacją zjawisk. Wyrażenia metaforyczne narzucają więc określone rozpoznanie świata, stają

6 J. Surman, Historyzowanie nauki lub jak nowe przychodzi na świat. Rozmowa z Hansem-Jörgiem Rheinbergerem, „Historyka. Studia Metodologiczne” t. 44, 2014, s. 57.

7 L. Fleck, O niektórych swoistych cechach myślenia lekarskiego, „Archiwum Historii i Filozofii Medycyny oraz Nauk Przyrodniczych" t. 6, 1927, z. 1, s. 55-64. 
się swego rodzaju modelami heurystycznymi. [...] Tak np. metafory wzięte z potocznego doświadczenia antropomorfizują rzeczywistość badaną, wzięte z mechaniki zaś mechanicyzują rzeczywistość, z fizyki - fizykalizują, itp. ${ }^{8}$

To nie przypadkowe zestawienie cytatów, pochodzących z różnych epok i środowisk historiograficznych, reprezentują one bowiem niezależnie od czasu i miejsca ich powstania różne strony tego samego procesu.

Pierwszą cechę ów badacz przeszłości swojej dyscypliny bierze ze współczesnych mu paradygmatów, w których został wykształcony, drugą z dyskursów właściwych jego dyscyplinie, w procesie socjalizacji zawodowej. Obie przenosi w przeszłość w charakterze swoistej imputacji kulturowej. Jej wyobrażenie ma zatem kształt niekompletnego jeszcze, ale dojrzewającego z czasem, paradygmatu, w którym nasz badacz został wykształcony i wychowany. I którego znana mu postać jest postrzegana jako efekt docelowy historycznych ścieżek. Jego współczesny obraz staje się punktem odniesienia, podstawą porównań i ocen historycznych standardów racjonalności naukowej. To myślenie wyznacza kierunek „rozwoju" macierzystej dyscypliny badacza, a i sama metafora rozwoju, nad wyraz często używana w dyskursach naukowych, jest obecna np. w tytułach licznych czasopism medycznych („Rozwój...”, „Postępy...” itp.).

Uczony z przeszłości nie jest tu, jak tego chciał Znaniecki, autorytetem w sprawach "sprawdzianów prawdziwości”, nie stosuje się tu interpretacji z perspektywy teoretycznego współczynnika humanistycznego, zachowań poznawczych w ujęciu subiektywnoracjonalnym itp. A są to przecież standardy w studiach humanistycznych, choć wyrażane w różnych ujęciach terminologicznych. Współczesnego badacza przeszłości swojej dyscypliny interesują wprawdzie dawne standardy racjonalności naukowej i ideały nauki, ale tylko w takim zakresie, który pozwala określić drogi i bariery jej „rozwoju” zmierzające do jej obecnego, najbardziej „racjonalnego”, kształtu.

Historyk medycyny koncepcję choroby postrzega z perspektywy patogenezy, określającej strukturę narracji historyczno-medycznej zarówno w zakresie identyfikacji, jak i charakterystyki choroby. Niekiedy z wykorzystaniem współczesnych mu narzędzi diagnostycznych, praktyk leczniczych i zapobiegawczych. Takie usytuowanie koncepcji choroby w strukturach narracyjnych ma na gruncie polskim długą tradycję. Wynikało z przekonania, obecnego już u XIX-wiecznych dziejopisów, o kluczowej roli patologii w kształceniu medycznym, gdzie historia medycyny stanowiła naturalne zaplecze tego procesu edukacyjnego. Nie zauważając przy tym, że taka perspektywa znacznie ogranicza możliwość socjologicznej, psychologicznej czy behawioralnej interpretacji choroby. „Myślenie patogenezą" jako metaforą fundamentalną nie pozwala przy tym na dostrzeżenie jej ograniczeń w medycznych strukturach narracji historycznej ${ }^{9}$. W pewnym stopniu można to porównać do przywiązania, jakim uniwersytecki historyk darzy genezę badanych zjawisk, pozwalającą niejako samoistnie, jak sądzi, je wyjaśnić.

Struktura narracji naukowej i dydaktycznej poddaje się tym procesom, konstruując spójne, logiczne wizje „rozwoju” danej nauki, niekoniecznie w zgodzie z chronologią

8 W. Wrzosek, Historia - kultura - metafora. Powstanie nieklasycznej historiografii, Wrocław 1995, s. 43-44.

9 J. Jeszke, Koncepcje choroby w historycznych strukturach narracyjnych, „Historyka. Studia Metodologiczne” t. 48,2018 , s. $9-20$. 
i warunkami powstawania odkryć. Zjawisko to trafnie i jędrnie scharakteryzował na przykładzie historiografii fizyki Andrzej Kajetan Wróblewski:

Szczytem wszystkiego jest przepisywanie historii fizyki tak, aby lepiej zgadzała się naszymi obecnymi wyobrażeniami. [...] Niektórzy autorzy sądzą zapewne, że wzmianki historyczne są tylko materiałem ubarwiającym wykład, który ma na celu nauczyć studentów rozumienia fizyki, jej zasad, techniki i zastosowań. [...] Zdarza się też, jak widzieliśmy, że historię niektórych zagadnień przepisuje się tak, aby ugruntować przekazywane idee. Jeśli bowiem fizyka odznacza się porządkiem, to tak samo ma wyglądać historia. Jest to szczególnie niebezpieczne w tych przypadkach, gdy porządek logiczny jest akurat odwrotny od porządku chronologicznego. Innym spotykanym czasem podejściem autorów współczesnych jest pobłażliwe traktowanie starych osiągnięć i wręcz przeciwstawienie im obecnych „dobrych" poglądów tym starym, naiwnym, błędnym. Błędy zdarzają się, jak powiedziałem, nie tylko w podręcznikach fizyki, lecz także w książkach o historii fizyki, gdzie widocznie też autorzy starają się pokazać „logiczną" historię rozwoju idei ${ }^{10}$.

Ma to stanowić rodzaj propedeutyki do badań naukowych, i w przypadku historii medycyny taką funkcję pełni już ok. 200 lat. To oznacza, że w „paradygmatycznym” ujęciu historiografii danej nauki są wychowywane kolejne generacje jej adeptów. Szereg wątpliwości może budzić przypisanie roli historyka badaczowi, który charakteryzuje się taką postawą do przeszłości swojej nauki. Wszak dzieje dyscypliny pełnią tu ściśle określoną rolę teoretyczną, metodologiczną, etyczną, dydaktyczną, inne cele badań mają charakter uboczny, jeżeli w ogóle zostają uwzględnione. W pewnym sensie można takiego badacza porównać do antropologa kultury, który do historii społecznej sięga tylko w takim zakresie, w jakim jest mu ona niezbędna do zrozumienia kultury współczesnej. Ale on nie udaje historyka.

To oczywiście nie jedyna funkcja tego nurtu w przypadku historiografii medycyny. Inną, o bardziej kulturowym niż teoretycznym charakterze, jest kształtowanie postaw etycznych środowisk medycznych oraz kultywowanie tradycji zawodowych je spajających. Nurtem historiografii medycznej, łączącym owe pola: teoretyczne, etyczne i kulturotwórcze, jest ten poświęcony ukazaniu polskich priorytetów wśród światowych odkryć w medycynie i walki o ich uznanie. Taka perspektywa studiów historyczno-medycznych nie pozostawia wiele miejsca dla analiz czynników kulturowych, kształtujących idee i drogi kształtowania się medycyny, czy też praktyk terapeutycznych niezgodnych ze współczesnymi poglądami naukowymi. Jest jednak spójna teoretycznie. Można tu mówić o paradygmacie historiograficznym ${ }^{11}$. W tym modelu badań zawodowy historyk nie może odegrać istotnej roli. Nie ma kompetencji medycznych, jego badania i aktywność zawodowa nie mogą być źródłem kreowania podstaw propedeutycznych i etyki zawodów medycznych i nie jest kulturowo związany z którymkolwiek z nich na tyle, aby się z nim identyfikować. Jego przydatność w tym kręgu badaczy ogranicza się do wdrożenia tam podstaw warsztatu historycznego, ale już nie do interpretacji dokonanych przy jego użyciu ustaleń.

Zgoła nieuprawnionym wnioskiem, wyprowadzonym z dotychczasowych rozważań, byłoby jednak stwierdzenie, że specjalista, lekarz, chemik, biolog, geograf etc. nie może wystę- 
pować jako profesjonalny historyk swojej nauki. Ogromnie ważne jest natomiast określenie roli w jakiej przystępuje on do badania przeszłości swojej dyscypliny. Ucinając wieloletnie już dyskusje o kompetencjach historyka nauki, należy z mocą stwierdzić, iż przeciwnie, jest w tej roli absolutnie niezbędny ze względu na swoje specjalistyczne kwalifikacje. Żaden historyk o uniwersyteckim w tej dziedzinie wykształceniu nie jest przecież w stanie zidentyfikować symptomów chorobowych na podstawie źródeł historycznych, takoż zinterpretować charakteru warsztatu alchemicznego itp. Kluczowa natomiast jest zmiana optyki prowadzenia studiów nad przeszłością w przypadku przyjęcia roli historyka.

Nie chodzi tu oczywiście wyłącznie o podstawowy warsztat historyka, dotyczący krytycznej pracy na źródłach. Te kompetencje posiadają także badacze, przyjmujący scharakteryzowaną wcześniej postawę, nazwaną tu roboczo „metodologiczną”. Najczęściej uzyskane poza regularnym studium, drogą samokształcenia. Gdyby bowiem ograniczyć zajmujących się przeszłością swoich dyscyplin specjalistów tylko do tej roli, sprowadzałaby się ona do ekspertyz wykonywanych na zlecenie historyków, w obrębie projektowanych przez nich badań. Takie sytuacje mają oczywiście swoje miejsce i wagę w studiach nad przeszłością wiedzy, jednakże nie określają jeszcze dostatecznie roli historyka danej nauki. Taki ekspert pracuje bowiem jako wykonawca szczegółowego zadania gotowego projektu historycznego, na którego założenia nie miał większego wpływu.

I tu rzecz nie jest całkiem prosta. Dla badań nad dawnymi kulturami medycznymi przedstawiciele tego nurtu historiograficznego są niezbędni, gdyż, jak wskazano, angażują ustalenia współczesnych nauk, np. medycznych i farmaceutycznych, do interpretacji technik terapeutycznych minionych epok i cywilizacji z perspektywy oceny ich skuteczności. Technologie medyczne mogą też wydobyć ze źródła historycznego informacje niedostępne w inny sposób. Jednakże wyniki takich studiów także bywają interpretowane w metaforach i kategoriach współczesnych nauk medycznych, nie zawsze przystających do ujęć narracyjnych historyka czy antropologa kultury. Wymagają zatem swoistej „translacji" pomiędzy tymi grupami badaczy. Można by przywołać tu przykłady także z kręgu innych nauk.

Przyjęcie roli historyka wymaga akceptacji ideałów nauki, teorii, doktryn, standardów racjonalności naukowej, praktyk poznawczych i ich społecznych konsekwencji, także terapeutycznych - jako konstruktów kulturowych uwarunkowanych historycznie. „Myśląc Kmitą", chodzi o akceptację teoretycznego współczynnika humanistycznego wraz z właściwymi obszarami praktyki społecznej. Dla np. historyka medycyny kluczowe będzie zrozumienie koncepcji zdrowia i choroby, obowiązującej w danej epoce historycznej w obrębie wizji świata i człowieka, związanych z nią metafor fundamentalnych itp. Od obowiązujących w tym zakresie idei zależały konkretne doktryny medyczne, formy terapii, a nawet to, czy dostrzegano potencjalnie dostępne wówczas możliwości terapeutyczne, jeżeli były one sprzeczne z kulturowym wzorcem postrzegania choroby i jej leczenia.

Dostrzeżenie zmienności kulturowych uwarunkowań w postaci wizji świata i człowieka, a więc także ideałów nauki i np. koncepcji zdrowia i choroby, a w dalszej kolejności rewolucji naukowych, zachodzących w dyscyplinach szczegółowych, zmienności prawomocności doktryn medycznych, prawnych itp. należy właśnie do zadań historyka. Przyjmujący rolę historyka przedstawiciel danej dyscypliny powinien - z jej perspektywy - odnaleźć się w tak zarysowanym procesie poznawczym. Procesy zmienności analizują historycy kultury, gospodarki, wojskowości itp. Historia nauki, choć jako dyscyplina graniczna 
musi zmierzać się z licznymi problemami, wynikającymi z takiego jej statusu, nie może być tu wyjątkiem. Daje to oczywiście prawo do sięgania do kategorii porównawczych, stosowanych przecież w naukach historycznych od dawna, w procesie interpretacji kierunków kształtowania się danej dyscypliny naukowej. Jednak podstawą wartościowania nie mogą być, powtórzmy, współczesne badaczowi teorie i standardy racjonalności naukowej. To linia demarkacyjna, oddzielająca historyka danej dyscypliny z niej się wywodzącego od szperaczy w jej przeszłości, kierujących się innymi motywami poznawczymi.

Czy takie usytuowanie pozbawia dziejopisa o „dyscyplinarnych" kompetencjach możliwości ich teoretycznego wykorzystania, bez wychodzenia z roli historyka swojej nauki? Otóż niekoniecznie. Interpretacja kierunków przekształcania się form „dyscyplinarnych" musi być dokonana przy ich wykorzystaniu. Jedną z szans jest m.in. przyjęcie perspektywy historiografii nauki jako autorefleksji kultury poznającej wobec kultury poznawanej, a można przecież bezpiecznie mówić o kulturach naukowych. Jak pisze Jan Pomorski:

W tym ujęciu historiografia jest jednym z istniejących (w danym miejscu i czasie) sposobów społecznego poznawania i społecznego urządzania (czasami mówi się też: „oswajania”) świata ludzkiego, tym odróżniającym się od innych, że jej podstawą - bazą empiryczną dla prowadzonych badań - są utrwalone i zachowane przekazy źródłowe, zawierające skumulowane doświadczenie społeczne przeszłych pokoleń. Jest historiografia nie tyle dostarczycielką wiedzy o przeszłości (choć tak najczęściej bywa, błędnie dodajmy, postrzegana), ale autorefleksją pokolenia, zapisem jego samowiedzy kulturowej [podkreślenia J.P.], utrwalonym w postaci tekstów historiograficznych ${ }^{12}$.

Koncepcję tę Jan Pomorski rozwija od lat dziewięćdziesiątych ubiegłego wieku, szukając inspiracji w społeczno-regulacyjnej interpretacji kultury Kmity ${ }^{13}$ i jego szkole naukowej, do związków z którą sam skąd inąd się przyznaje. Uczony akceptująco przywołuje istotne dla historyka nauki poglądy Margaret S. Archer:

Jej zdaniem to, jak ludzie prowadzą wewnętrzny dialog ma kluczowe znaczenia zarówno dla ich osobistych i społecznych tożsamości, jak i dla skuteczności działań przez nich podejmowanych w obrębie rozmaitych praktyk społecznych. Zwłaszcza w nauce doświadczenie ciągłości i nieciągłości kontekstu działania, rozpatrywane zarówno $w$ wymiarze systemowym, jak i biograficznym ma tu znaczenie. Wspólnota doświadczeń podzielana z innymi znaczącymi (np. autorytetami w danej dyscyplinie naukowej) umożliwia kulturze poznającej zachowanie ciągłości kontekstowej, którego efektem są powtarzalne sytuacje, stabilne oczekiwania i trwałe związki14, a poszczególne odmiany wewnętrznej konwersacji wyłaniają się na styku między kontekstami a wspólnotowo podzielanymi troskami ${ }^{1516}$.

12 J. Pomorski, Homo metahistoricus. Studium sześciu kultur poznających historię, Lublin 2019, s. 5.

13 G. Banaszak, J. Kmita, Społeczno-regulacyjna koncepcja kultury, Warszawa 1991.

14 M.S. Archer, Making our Way through the World: Human Reflexivity and Social Mobility, Cambridge 2007, s. 49.

15 Eadem, Structure, Agency and Internal Conversation, Cambridge 2003, s. 345.

16 J. Pomorski, op. cit., s. 4-5. 
Uważa on, że

zdolność do [...] obiektywizacji na poziomie refleksji nad własną historią, ma charakter poznawczy (podmiotowa zdolność do rozpoznania i opisywania biegu zdarzeń w ich powiązaniu), a właściwiej byłoby powiedzieć nawet: społeczno-poznawczy (bowiem w roli podmiotu mogą wystąpić grupy społeczne, od rodziny po narody), i oznacza z jednej strony zdolność do działania na poziomie reprezentacji dziejów, [...] a z drugiej zdolność do wyrwania wydarzeń z niebytu, czyli nienazwania i niepamięci. Ten rodzaj obiektywizacji to:

(1) artykulacja / nazwanie zaistnienia czegoś (bytu/ wydarzenia historycznego, o określonych współrzędnych czaso-przestrzennych) oraz (2) utrwalenie pamięci o konkretnym wytwarzaniu w historii, dziejącym się "tu i teraz", co nazywam podmiotowym doświadczaniem historii, poprzez opowiedzenie o nim, opisanie go/ich w formie jakiegoś przekazu ${ }^{17}$.

Pomorski zwraca tu uwagę na

odróżnianie dwóch postaw wobec rzeczywistości historycznej: (1) postawy sprawcy historii, działającego indywidualnie lub/i zbiorowo oraz (2) postawy reflektującego nad własną historią (jednostka lub podmiot zbiorowy, np. naród), co przekłada się w moim języku teoretycznym na dwa pojęcia, jakimi dalej będę się posługiwał: homo historicus na oznaczenie człowieka jako sprawcy Historii (dziejo-twórcy) oraz homo metahistoricus na oznaczenie osoby reflektującej nad historią (np. historyka, choć nie tylko) ${ }^{18}$.

Idąc tropem retoryki swojego (i mojego) mistrza, Jerzego Topolskiego, Pomorski konstatuje, że

nauka jest jednym z typów praktyki społecznej i że również ona ma swoje reguły sterujące przebiegiem działań w obrębie tej praktyki podejmowanych. Z kolei przemyśliwanie nad zmianami, jakie w obrębie społecznej praktyki naukowej zachodzą w czasie jej praktykowania (tj. w historii nauki, w tym w historii samej historiografii), pozwoliło dostrzec, iż sama granica naukowości zmienia się historycznie, i że wszelkie poznanie ma charakter nie ponadczasowy, lecz historyczny ${ }^{19}$.

Autorefleksję kultury poznającej, obecną w jej historiografii, w analizowanym tu przypadku: nauki, postrzega Pomorski bądź jako zapis samowiedzy danej generacji badaczy, bądź uwikłania konkretnego historyka w kulturę naukową jego czasu, wpływające na jego interpretację przeszłości. Z tej ostatniej perspektywy interpretuje postawy badawcze Jerzego Topolskiego, Zdzisława Cackowskiego i Krzysztofa Pomiana oraz odczytuje role kultury poznającej w pracach Marca Blocha, Timothy Snydera i Andrzeja Nowaka ${ }^{20}$.

Kwestią odrębnego i znacznie obszerniejszego studium jest adaptacja przedłożonej tu koncepcji historiografii jako autorefleksji kultury poznającej w obszar historiografii nauki. 
Jednakże można bez trudu zauważyć, że innymi cechami charakteryzuje się np. pozytywistyczna metodologia badań historyczno-medycznych, polska szkoła medycyny "filozoficznie ujęta" doby międzywojennej czy marksistowskie, niekiedy raczej pseudomarksistowskie interpretacje dziejów medycyny w okresie PRL-u. W każdym z tych wariantów studiów historyczno-medycznych, i w wielu innych, można mówić o relacjach określonej kultury poznającej wobec minionej kultury poznawanej, w tym przypadku medycznej, gdyby przyjąć perspektywę interpretacyjną Pomorskiego. Można jednak w to miejsce wstawić dowolną dyscyplinę naukową i rozważać stosunek środowisk jej badaczy, rozumianych jako kultura poznająca, do swojej przeszłości i jej znaczenia dla tej pierwszej. Na taką kulturę składają się bowiem nie tylko obowiązujące w danym miejscu i czasie ideały nauki, paradygmaty czy doktryny, ale postrzegany przez daną społeczność naukową zestaw wartości, cele, jakie stawia sobie dana dyscyplina, kwestie etyczne itp. Zmiana cech danej naukowej kultury poznającej oznacza odmienne, ale zawsze wzajemne, relacje z przeszłością jako kulturą poznawaną. Zmienny namysł nad tą ostatnią, uwidoczniony na łamach tekstów historycznych, tworzy właśnie ową autorefleksję nad poznawaną kulturą naukową.

Można w tych kategoriach rozpatrywać np. monumentalną Historię fizyki Andrzeja Kajetana Wróblewskiego, który jasno określa charakter refleksji nad przeszłością fizyki. „W tej książce - pisze - zdecydowałem się przedstawić rozwój tych zagadnień, które zalicza się do fizyki dziś, niezależnie od tego jak traktowano je dawniej"21, przyznając, że

aby właściwie zrozumieć i przedstawić stan fizyki w jakiejś odległej epoce, trzeba postarać się „wejść w skórę" działających wtedy uczonych, naśladować ich sposób myślenia i pojmować ich ograniczenia. Musimy postarać się „podsłuchać” miniony czas. Inaczej łatwo jest wyciągać fałszywe i nieuzasadnione wnioski22.

\section{Jednakże}

nie rozważam pomysłów ważnych, które nie były znane uczonym w danej epoce. Nawet najbardziej genialne odkrycie, nieopublikowane albo znane tylko wąskiemu gronu, nie przyczyniło się do rozwoju nauki²3.

Nietrudno sobie jednak wyobrazić przedstawicieli kultury poznającej, wywodzących się z kręgu nauk fizycznych, odmiennie rozkładających akcenty w swojej autorefleksji nad przeszłością, choćby wobec ostatniej kwestii.

Byłoby, jak sądzę, również niezwykle interesujące prześledzić, jak np. w procesie takiej autorefleksji ulegały zmianie stanowiska środowisk chemicznych do alchemii wraz ze zmianą cech ich kultury poznającej. Na to zjawisko zwrócił uwagę Rafał T. Prinke, pisząc, że

właśnie historiografa alchemii stanowi najlepszy przykład ułomności wiedzy prezentowanej przez wielu historyków nauki jako wiedza pewna, podczas gdy w rzeczywistości (z nielicznymi wyjątkami) wydobywali oni z owocu same nasiona, tylko one bowiem miały dla nich wartość, nie byli bowiem zainteresowani poznaniem 
całego owocu, jego kształtu, koloru, zapachu²4. Na początku ostatniej dekady minionego stulecia nastąpił wyraźny zwrot w stronę badania całego owocu, przy jednoczesnym wzroście zainteresowania dziejami alchemii wśród historyków różnych specjalności ${ }^{25}$.

Wyposażenie teoretyczne „dziejopisa-specjalisty” bierze oczywiście udział w procesie kształtowania się relacji kultura poznająca - miniona kultura poznawana jako jeden z jej podstawowych elementów, właściwych danej dziedzinie nauki. Jednakże w roli autorefleksji, a nie wartościowania, a to fundamentalna różnica. Badacz przyjmujący taką rolę jawi się jako swoisty homo metahistoricus swojej dziedziny nauki, jak chce Pomorski.

W 1937 r. Znaniecki napisał ważny, przywołany już, artykuł Społeczne role uczonych a historyczne cechy wiedzy ${ }^{26}$. Jego myśl, stanowiąca dla mnie inspirację, mogłaby także zamknąć klamrą niniejsze rozważania. Dziejopis nauki, wykształcony w kulturze zawodowej jednej z jej dyscyplin, patrząc w przeszłość przyjmuje różne role. Przywołane w tym tekście pełnią jedynie funkcję przykładu. Każda z nich jest równoprawna i taki badacz może czuć się dobrze w więcej niż jednej z nich. Jednakże każdorazowo powinien zostać jasno wyartykułowany cel poznawczy i określona społeczna rola uczonego ów cel realizującego. Niektóre nie wymagają przyjęcia społecznej roli historyka.

\section{Bibliografia}

Archer M.S., Structure, Agency and Internal Conversation. Cambridge 2003.

Archer M.S., Making our Way through the World: Human Reflexivity and Social Mobility, Cambridge 2007.

Banaszak G., Kmita J., Społeczno-regulacyjna koncepcja kultury, Warszawa 1991.

Fleck L., O niektórych swoistych cechach myślenia lekarskiego, „Archiwum Historii i Filozofii Medycyny oraz Nauk Przyrodniczych" t. 6, 1927, z. 1, s. 55-64.

Jeszke J., W poszukiwaniu paradygmatu polskiej historiografii medycznej, Poznań 2000.

Jeszke J., Koncepcje choroby w historycznych strukturach narracyjnych, „Historyka. Studia Metodologiczne" t. 48, 2018, s. 9-20, DOI 10.24425/hsm.2018.124605.

Kmita J., Szkice z teorii poznania naukowego, Warszawa 1976.

Pomorski J., Homo metahistoricus. Studium sześciu kultur poznających historię, Lublin 2019.

Prinke R.T., Zwodniczy ogród błędów. Piśmiennictwo alchemiczne do końca XVIII wieku, Warszawa 2014.

Rheinberger, H-J., Epistemologia historyczna, tłum. J. Surman, Warszawa 2015.

Surman J., Historyzowanie nauki lub jak nowe przychodzi na świat. Rozmowa z Hansem-Jörgiem Rheinbergerem, „Historyka. Studia Metodologiczne” t. 44, 2014, s. 51-65.

24 Parafraza opinii odnoszącej się do Hermanna Koppa, jednego ze znakomitych historyków alchemii XIX w., celnie opisującą sytuację w całej historiografii alchemii, cyt. za R.T. Prinke, Zwodniczy ogród błędów. Piśmiennictwo alchemiczne do końca XVIII wieku, Warszawa 2014, s. 11.

25 Ibid.

26 F. Znaniecki, Społeczne role uczonych, s. 520-602. 
Wróblewski A.K., Historia fizyki. Od czasów najdawniejszych do współczesnych, Warszawa 2007.

Wróblewski A.K., Prawda i mity w fizyce, Wrocław 1982.

Wrzosek W., Historia - kultura - metafora. Powstanie nieklasycznej historiografii, Wrocław 1995.

Wrzosek W., O myśleniu historycznym, Bydgoszcz 2009.

Znaniecki F., Przedmiot i zadania nauki o wiedzy, „Nauka Polska. Jej potrzeby, organizacja i rozwój" t. 5, 1923, s. 1-78.

Znaniecki F., Społeczne role uczonych a historyczne cechy wiedzy (1937), [w:] idem, Społeczne role uczonych, tłum. i red. J. Szacki, Warszawa 1984, s. 520-602.

dr hab. Jaromir Jeszke, prof. UAM, historyk nauki i antropolog wiedzy. Profesor w Uniwersytecie im. Adama Mickiewicza w Poznaniu w Wydziale Pedagogiczno-Artystycznym w Kaliszu. Wiceprzewodniczący Komitetu Historii Nauki i Techniki PAN. Redaktor Naczelny Rocznika Kasy im. J. Mianowskiego „Nauka Polska Jej Potrzeby, Organizacja i Rozwój". W swoich badaniach podejmuje problematykę historii i antropologii wiedzy medycznej, historii historiografii i metodologii badań nad nauką, komunikacji idei w dziejach nauki. Zajmuje się także problematyką roli historii w procesie komunikacji międzykulturowej.

e-mail: jeszke@amu.edu.pl

Data zgłoszenia artykułu: 13 grudnia 2020

Data przyjęcia do druku: 7 stycznia 2021 